AUTHORS:

Noluthando C. Netnou-Nkoana ${ }^{1}$

Julian B. Jaftha ${ }^{1}$

Mabjang A. Dibiloane ${ }^{1}$

Jacobus Eloff ${ }^{2}$

\section{AFFILIATIONS:}

Department of Agriculture, Forestry and Fisheries, Pretoria, South Africa

2Phytomedicine Programme, Department of Paraclinical

Sciences, Faculty of Veterinary Sciences, University of Pretoria, Pretoria, South Africa

\section{CORRESPONDENCE TO:}

Noluthando Netnou-Nkoana

\section{EMAIL:}

NoluthandoN@daff.gov.za

\section{POSTAL ADDRESS:}

Department of Agriculture, Forestry and Fisheries, Private Bag X973, Pretoria 0001, South Africa

\section{DATES:}

Received: 05 Nov. 2013

Revised: 07 Jan. 2014

Accepted: 23 Feb. 2014

\section{KEYWORDS:}

South Africa; plant breeders' rights; farmers' privilege; smallholders; farmers

\section{HOW TO CITE:}

Netnou-Nkoana NC, Jaftha JB, Dibiloane MA, Eloff J. Understanding of the farmers' privilege concept by smallholder farmers in South Africa. S Afr J Sci. 2015;111(1/2), Art. \#2013-0344, 5 pages. http://dx.doi.org/10.17159/ sajs.2015/2013-0344

\section{(C) 2015. The Author(s).} Published under a Creative Commons Attribution Licence.

\title{
Understanding of the farmers' privilege concept by smallholder farmers in South Africa
}

\begin{abstract}
Legislation on plant breeders' rights - the Plant Breeders' Rights Act, 1976 (Act No. 15 of 1976) - currently is being reviewed by the Department of Agriculture, Forestry and Fisheries. This legislation provides for farmers' privilege, which is one of the exceptions to plant breeders' rights. It allows farmers to save seed of protected varieties for their own use. Farmers' privilege, and particularly its impact on smallholder farmers in developing countries, is a widely debated issue. During the public consultation process, several comments proposing amendments to the farmers' privilege provision were received from various stakeholders. However, no comments were received from the smallholder farmers who may be directly impacted by this provision. This pilot study was undertaken to assess the understanding of the farmers' privilege concept by smallholder farmers from the historically disadvantaged communities and their current practices with regard to seed saving. The results showed that the majority of the smallholder farmers were not aware of the existence of the legislation on plant breeders' rights and therefore do not understand the farmers' privilege concept and its implications. They also did not know whether the varieties they were using were protected by plant breeders' rights or not. Little information has been published on the impact of plant breeders' rights in South Africa in general. We hope that this study might inform policy decisions on matters related to plant breeders' rights and the farmers' privilege.
\end{abstract}

\section{Introduction}

The Agreement on Trade-Related Aspects of Intellectual Property Rights (TRIPS) requires that all countries that are members of the World Trade Organization provide a minimum level of intellectual property protection in their national laws. ${ }^{1}$ Botanical innovation resulting in the creation of new plant varieties is afforded legal protection through intellectual property rights (IPRs) - specifically, plant breeder's rights and patents. ${ }^{2}$ Article 27 (3)(b) of the TRIPS agreement provides that members shall provide for the protection of plant varieties either by patents or by an effective sui generis system ('of its own kind' meaning 'unique in its characteristics') or by any combination thereof. The major parameters of most common sui generis protection systems involve the so-called 'farmers' privilege'. The farmers' privilege provides the farmer with some exemptions to IPRs, ranging from the right to save seed for his or her own use to the right to exchange or sell seed, depending on the national law. ${ }^{3}$

Plant variety protection, also called 'a plant breeder's right', is an exclusive right, granted to the breeder of a new plant variety, to exploit their variety. It is a form of IPR; other examples of such rights are patents, copyrights, trademarks and industrial designs. ${ }^{4}$ The plant breeders' rights model developed in The International Union of the Protection of New Varieties (UPOV) Convention has been seen as an acceptable sui generis system that fulfils the requirements of the TRIPS agreement in this field. ${ }^{5}$ The mission of UPOV is to provide and promote an effective system of plant variety protection, with the aim of encouraging the development of new varieties of plants, for the benefit of society. ${ }^{6}$ The UPOV Convention was adopted in Paris in 1961 and it was revised in 1972, 1978 and 1991.

The farmers' privilege describes the agricultural tradition of farmers saving part of their harvest for the seeding or propagation of the next crop. ${ }^{7}$ There is no reference in the 1978 UPOV Convention to the right of farmers to re-sow seed harvested from protected varieties for their own use. The Convention establishes minimum standards such that the breeder's prior authorisation is required for at least three acts: the production for purposes of commercial marketing, the offering for sale and the marketing of the reproductive or vegetative propagating material, as such, of the variety. Thus, countries that are members of the 1978 Convention are free to either uphold farmers' privilege or eliminate it. All UPOV member countries implemented the exemption for 'private and non-commercial use' under the UPOV Act of 1978 to include the re-sowing and, in some cases, the local exchange or sales of seed, ${ }^{8}$ at least for some crops.

With the UPOV Convention of 1991, the provision on 'farmers' privilege' is an optional benefit-sharing mechanism provided by the UPOV Convention, under which UPOV members may permit farmers, on their own farms, to use part of their harvest of a protected variety for the planting of a further crop. Under this provision, members of UPOV are able to adopt solutions, which are specifically adapted to their agricultural circumstances. However, this provision is subject to reasonable limits and requires that the legitimate interests of the breeder are safeguarded to ensure there is a continued incentive for the development of new varieties of plants, for the benefit of society. For example, certain members of UPOV apply the provision on farm-saved seed only to certain species or limit its application using criteria such as the size of the farmer's holding or the level of production ${ }^{9}$ or in such a way that only farmers with large farms have to pay royalties on the reuse of farm-saved seed.

South Africa has been a member of the UPOV Convention since 1977 and is bound by the 1978 UPOV Convention. Intellectual property protection for new plant varieties is afforded through the Plant Breeders' Rights Act, 1976 (Act No.15 of 1976) which is administered by the Department of Agriculture, Forestry and Fisheries (DAFF). DAFF is currently reviewing the Plant Breeders' Rights Act and one of the provisions that attracted interest from various stakeholders is the provision on farmers' privilege. This contribution investigates the understanding of the farmers' 
privilege concept by smallholder farmers from previously disadvantaged communities as well as their current practices with regard to seed saving.

\section{Farmers' privilege provision in South Africa}

Farmers' privilege is provided for in Section 23 of the Plant Breeders' Right Act, 1976. This section stipulates that farmers' privilege is provided to

\begin{abstract}
a farmer who on land occupied by him or her uses harvested material obtained on such land from that propagating material for purposes of propagation: Provided that harvested material obtained from replanted propagating material shall not be used for purposes of propagation by any other person other than that farmer.
\end{abstract}

The provision excludes exchange of protected varieties among farmers. This section was inserted in the Plant Breeders Rights Amendment Act, 1996 and is modelled around Article 15 of UPOV 1991.

A major reason that plant variety protection does not elicit greater investment in commercial seed production for open-pollinated varieties is the difficulty of limiting farmers' seed saving and exchange. ${ }^{1}$ UPOV 1991 offers a solution to this problem, by prohibiting seed saving of the protected seed (except for specifically designated crops) and eliminating the possibility of seed exchange. However, for most farming systems in most developing countries, such restrictions would be politically explosive and impossible to enforce among farmers who are used to saving seed or obtaining it from their neighbours.

It is against this background that we decided that, as part of the reviewing process of the current legislation on plant breeders' rights, inputs should be solicited from various stakeholders, particularly on the farmers' privilege provision. Inputs were received from several stakeholders, including breeders, commodity groups, patent attorneys and commercial farmer representatives. However, no inputs were received from smallholder farmers. Smallholder farmers numbered approximately 225000 as of 2010 , belonging to about 150000 households, and are predominantly black. ${ }^{10}$

\section{Methodology}

In the absence of inputs from the smallholder farmers, we decided that workshops be held for historically disadvantaged smallholder farmers or their representatives. Workshops for this pilot study were held in the Eastern Cape, the Free State, Limpopo and Western Cape Provinces. Participants for the workshops were mainly invited through the extension officers working for Provincial Departments of Agriculture, except for the Western Cape where the participants were organised by civil society organisations that work in the interests of smallholder and subsistence farmers.

During these workshops:

- A presentation on the plant breeders' rights system and farmers' privilege was given. Discussions on the practice of saving seed were conducted.

- Questionnaires with basic questions on the Plant Breeders' Rights Act and the farmers' practices on saving seed were distributed to all participants. Questions most relevant to this study are depicted in Appendix 1. The participants were assisted to complete the questionnaires by the extension officers who explained the questions in the participants' languages.

\section{Results}

\section{Discussions on saving seed}

During the discussions with the participants, it was evident that farmers' opinions differed with regard to the practice of saving seed. Some farmers were in favour of seed saving while others were against the practice. The following arguments were put forward:
For saving seed:

- $\quad$ Saving, sharing and exchange of seeds are ancient practices within communities and must be allowed in the legislation.

- Selling of protected seed by smallholder farmers should be allowed (for surplus seed).

Against saving seed:

- Saving of seed should not be allowed as it compromises the quality of seed.

\section{Results from questionnaires}

The number of participants

A total of 187 farmers/farmer representatives participated in this study, with $40 \%$ from the Free State Province, 26\% from Limpopo Province, 23\% from the Western Cape Province and 11\% from the Eastern Cape Province.

\section{Size of land under cultivation}

The area under cultivation ranged between 1 ha and 5 ha, with the tenure ranging from communal to leased or self-owned land.

\section{Familiarity with the Plant Breeders' Rights Act}

The respondents differed in their familiarity with the Plant Breeders' Rights Act (Figure 1). Overall, and in all provinces except the Western Cape, most participants were not familiar with the Act.

\section{Practice of saving seed}

There were major differences in the percentage of respondents from different provinces who indicated that they do save seed compared with respondents who indicated that they do not save seed. These differences are shown in Figure 2.

\section{Types of crops from which seed is saved}

Respondents listed the following crops from which they saved seed: maize, sorghum, soya beans, wheat, potato, apricot, beans, beetroot, butternut, cabbage, carrot, chillies, green pepper, onion, peas, plum, pumpkin, spinach, strawberry, tomato and watermelon. We note that not only seed-propagated crops were listed, but that vegetatively propagated crops were also listed by some respondents.

\section{Discussion and conclusions}

It is estimated that African farmers depend on seeds cultivated within their communities for as much as $90 \%$ of their seed needs. According to IPR expert Andrew Mushita:

$$
\begin{aligned}
& \text { All resources belong to everyone and they are } \\
& \text { regulated by the community's cultural and local } \\
& \text { knowledge systems and practices. In this sense, } \\
& \text { farmers have exchanged seeds among themselves } \\
& \text { since time immemorial, passing from neighbour } \\
& \text { to neighbour, mother to daughter, mother-in- } \\
& \text { law to daughter-in-law, or even across villages } \\
& \text { and communities. }{ }^{11}
\end{aligned}
$$

Farmer seed saving is one of the most contentious issues related to plant variety protection ${ }^{4}$, is very sensitive and has political implications ${ }^{12}$. In both Europe and the USA, seed saving has become one of the most hotly disputed aspects of IPR in agriculture. ${ }^{13}$ The issue of seed saving is a good example of how IPRs in plant breeding must be tailored to the conditions of national seed systems. ${ }^{4}$

In South Africa, little is recorded on the understanding of the impact on IPR, particularly plant breeders' rights on smallholder farmers mainly from historically disadvantaged groups. 


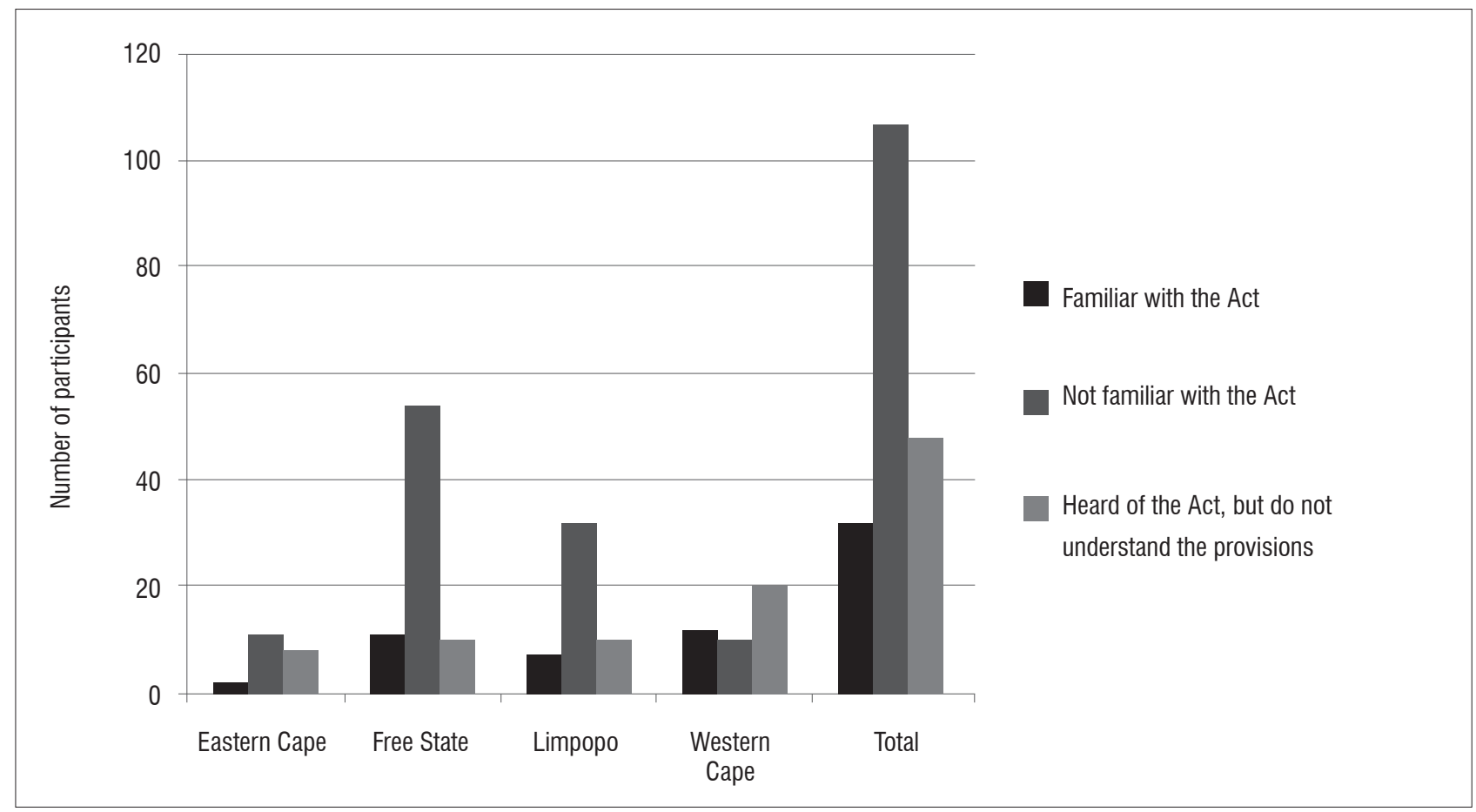

Figure 1: Familiarity with the Plant Breeders' Rights Act among participants from different provinces.

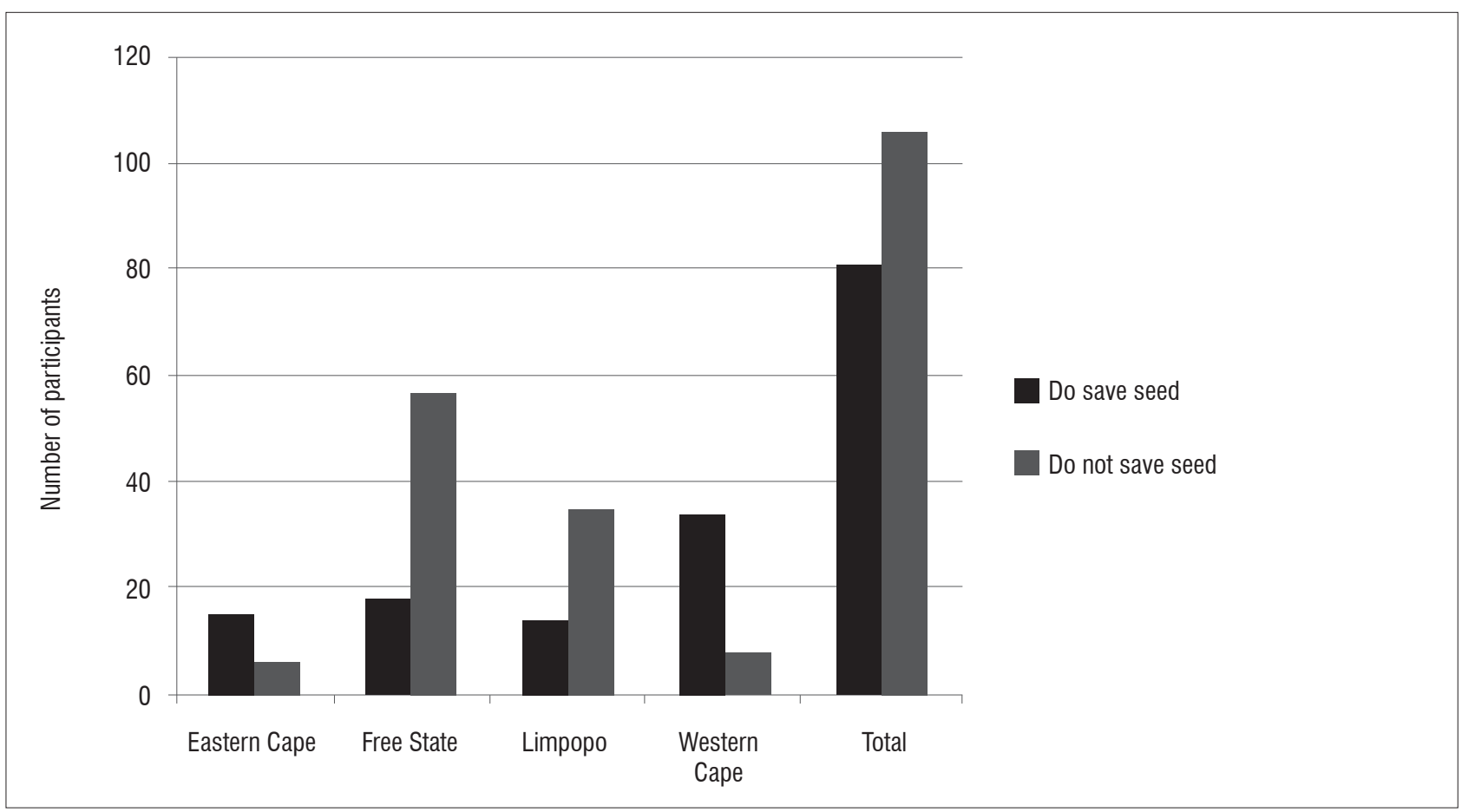

Figure 2: Practice of saving seed among participants from different provinces.

Of the total number of respondents, $57 \%$ indicated that they had never heard of the Plant Breeders' Rights Act before, 18\% were familiar with the Act and $25 \%$ had heard of the Act but did not quite understand the provisions of the Act and how it impacted on them and their farming practices.

A majority of the respondents (57\%) indicated that they do not save seed, citing two main reasons:

1. They were advised by the extension officers to not save seed but rather to buy seed annually to ensure a good yield as they mostly used hybrid seed.
2. From their own experiences, saved seed did not produce good quality product. They preferred to buy seed annually and practice crop rotation.

During the discussions it was discovered that this group of respondents mainly used hybrid seed and hence the practice of saving seed was not encouraged.

Nearly half $(43 \%)$ of the respondents indicated that they do save seed. Respondents from Limpopo indicated that they save seed from both hybrids and open-pollinated varieties. They mostly use harvest from hybrid seed for feed in the following year. Respondents from the Eastern 
Cape indicated that they mostly save seed from their traditional crops and not from the hybrids sold by the commercial companies. Respondents indicated that seed is mainly saved for their own use but that they do exchange and sometimes sell seed to neighbours when they have a surplus. The main crops from which seed is saved are maize, sorghum, soya beans and wheat. It is interesting to note that respondents from the Western Cape also listed vegetable crops such as cabbage, butternut, carrot and spinach, but not fruit crops such as apricot.

There are smallholder farmers from previously disadvantaged communities who still practice the tradition of saving seed, and, in some cases, do exchange and sell this seed to their neighbours. These farmers are, however, neither familiar with the legislation on plant breeders' rights nor aware of the farmers' privilege concept. They indicated, however, that the seed they save is from their traditional varieties, and that they were not aware of any varieties that were protected by plant breeders' rights.

We conclude from this survey that:

1. Awareness of the Plant Breeders' Rights Act and the farmers' privilege concept is very low among smallholder farmers.

2. Some of the smallholder farmers interviewed considered that a future Plant Breeders' Rights legislation in South Africa should create some freedom for smallholders to continue their traditional practice of saving and exchanging seed. Further study may be useful to identify whether such exemption could be consistent with the UPOV Act of 1991.

This pilot study may assist policymakers in understanding the importance of engaging the smallholder farmers in discussions pertaining to legislation that has an impact on them. The participants appreciated the effort made by DAFF to engage with them as it was the first time they were involved in such discussions. This study highlights the need for further studies to establish the extent of seed-saving practices, particularly those using protected varieties, among smallholder farmers. This study also highlights the importance of ongoing dialogue between policymakers and non-governmental organisations representing the interests of smallholder farmers.

The participants also indicated that they do their own selection of some crops but were not aware that they could develop varieties that can be protected in terms of the Plant Breeders' Rights Act - they were under the impression that these pieces of legislation are meant for big companies which use modern breeding techniques.

This pilot study will contribute in assisting DAFF in developing norms and standards that may ultimately inform regulations pertaining to the application of farmers' privilege in South Africa.

\section{Acknowledgements}

This study was commissioned by the Directorate: Genetic Resources of the Department of Agriculture, Forestry and Fisheries, and they are thanked for their support. We thank the Head of Provincial Departments responsible for Agriculture in the Eastern Cape, Free State, Limpopo and Western Cape and their extension officers, the civil society organisations involved, the farmers and their representatives, industry representatives, DAFF officials and others who participated in this study for their contributions. Mashudu Mafenya and Malerotho Lekoane assisted with TshiVenda and Sepedi translations, respectively.

\section{Authors' contributions}

N.C.N-N., J.B.J. and M.A.D. contributed to the conceptual development of the paper and facilitation of the workshops. N.C.N-N. analysed the data and led the writing. J.E. provided guidance and valuable comments on the first draft of the manuscript.

\section{References}

1. Tripp R, Louwaars N, Eaton D. Plant variety protection in developing countries. A report from the field. Food Policy. 2007;32:354-371. http://dx.doi. org/10.1016/j.foodpol.2006.09.003

2. Fuavao VA. Intellectual property and agriculture. The Courier ACP-EU. 2003 Nov/Dec, no. 201;39-41.

3. The World Bank. Intellectual property rights: Designing regimes to support plant breeding in developing countries. Report no. 35517-GLB. Washington DC: The International Bank for Reconstruction and Development/ The World Bank; 2006. Available from: http://siteresources.worldbank.org/INTARD/ Resources/IPR_ESW.pdf

4. Thiele-Wittig M, Claus P. Plant variety protection - A fascinating subject. World Pat Inf. 2003;25(3):243-250. http://dx.doi.org/10.1016/S01722190(03)00074-7

5. Cullet P. Intellectual property rights and food security in the South. Geneva: International Law Research Centre; 2004. Available from: http://www.ielrc. org/content/a0403.pdf

6. Jördens R. Progress of plant variety protection based on the International Convention for the Protection of New Varieties of Plants (UPOV Convention). World Pat Inf. 2005;27:232-243. http://dx.doi.org/10.1016/j. wpi.2005.03.004

7. De Sà CD, Saes MSM. Intellectual property rights in the flower chain: An analysis of the Brazilian Plant Variety Protection System. VII International Pensa Conference; 2009 Nov 26-28; Sao Paulo, Brazil. Available from: http:// www.cors.usp.br/conferences/files/4.pdf

8. Dutfield G. The key global negotiations and agreements. Turning plant varieties to Intellectual Property: The UPOV Convention. Ottawa: International Development Research Center; 2008. Available from: http://www.academia. edu/863586/Turning_plant_varieties_into_intellectual_property_The_ UPOV_Convention

9. UPOV. Access to genetic resources and benefit sharing: Reply of UPOV to the notification of June 26, 2003, from the Executive Secretary of the Convention on Biological Diversity [document on the Internet]. c2003 [cited 2014 Dec 11]. Available from: http://ww.upov.int/export/sites/upov/news/en/2003/pdf/ cbd_response_oct232003.pdf

10. Integrated Growth and Development Plan. Pretoria: Department of Agriculture, Forestry \& Fisheries; 2012. Available from: www.daff.gov.za

11. Kuyek D. Intellectual property rights in African agriculture. Implications for small farmers [document on the Internet]. c2002 [cited 2014 Dec 11]. Available from: http://www.grain.org/article/entries/3-intellectual-propertyrights-in-african-agriculture-implications-for-small-farmers

12. Le Buanec B. Protection of plant-related innovations: Evolution and current discussion. World Pat Inf. 2006;28:50-62. http://dx.doi.org/10.1016/j. wpi.2005.10.002

13. Van Wijk J. How does stronger protection of intellectual property rights affect seed supply? Early evidence of impact. Nat Resour Perspect. 1996;13. Available from: http://www.odi.org/sites/odi.org/uk/files/odi-assets/ publications-opinion-files/2965.pdf 


\section{Appendix 1: Questionnaire distributed to participants}

1. FARM DETAILS:

1.1 Farm name:

1.2 Province:

1.3 District municipality:

1.4 Local municipality:

1.5 Village/town:

1.6 No. of hectares:

2. PLANT BREEDERS' RIGHTS ACT, 1976 (ACT NO. 15 OF 1976):

2.1 Are you familiar with the Plant Breeders' Rights Act which aims to protect the rights of breeders of new plant varieties? (Please tick the most appropriate)

Yes

No

Heard of it, but I do not understand it

\section{FARM-SAVED SEED}

3.1 Do you save seed from your harvest to use the following year?

Yes

No

3.2 If yes, please complete the table below:

\begin{tabular}{|c|c|c|}
\hline $\begin{array}{c}\text { Crop type (maize, wheat, etc.) and variety names } \\
\text { (if known) }\end{array}$ & No. of hectares under cultivation & $\begin{array}{c}\text { Do you save seed of varieties protected by plant } \\
\text { breeders' rights? } \\
\text { [yes (Y), no (N), do not know (D)] }\end{array}$ \\
\hline & & \\
\hline & & \\
\hline
\end{tabular}

3.4 Why do you save seed? (Please tick the most appropriate)

\begin{tabular}{|c|c|c|c|}
\hline Reason & Most important & Important & Least important \\
\hline i) To save money & & & \\
\hline ii) To sell to other farmers & & & \\
\hline iii) To exchange with other farmers & & & \\
\hline iv) For own use (in my own farm) & & & \\
\hline $\begin{array}{l}\text { v) To use in creating improved varieties } \\
\text { (e.g. selection) }\end{array}$ & & & \\
\hline $\begin{array}{l}\text { vi) To take it to cooperatives for further processing } \\
\text { (e.g. milling) }\end{array}$ & & & \\
\hline vii) Other: please specify & & & \\
\hline
\end{tabular}

